\title{
Histories of ethnicity, nation and migration
}

Nationhood, ethnicity and migration have been linked in south-east Europe, including the Yugoslav region, since the descendants of Slav clans who migrated there from Central Asia in the sixth to eighth centuries $\mathrm{CE}$ and others living there who came to share their collective identity started to understand themselves as nations - however long ago or recently that might be (Fine 2006). Ottoman rule in south-east Europe, moreover, both represented and caused further migration. The region's nineteenth- and twentieth-century history, however, is (in the prevailing paradigm) primarily a history of (what are constructed as) settled mono-ethnic nations forming states and engaging in territorial disputes which have often led to forced migration when perpetrators of ethnicised violence purge those they identify as minorities from what they intend as homogenous national territories, but which are rarely viewed in the context of migration around the globe.

Histories of 'race', however, are always and already migration histories. White Europeans' transoceanic movements, their conquest and acquisition of indigenous peoples' lands in the Americas, and their transportation of millions of enslaved Africans across the Atlantic are the acts of violence which 'race', in demarcating fully human and sovereign populations from those who were not, was constructed to enable and explain (Gilroy 1993). Outside postcolonial studies and anti-racist activism, white scholars are not used to calling these processes by names they use all the time to talk about collective violence in eastern Europe: displacement, forced migration, genocide. ${ }^{1}$ Transnational feminist histories of race and empire meanwhile reveal the everyday, intimate politics of global 
racial formations, where racialised ideologies of gender, sexuality and bodies circulated between colonised territories and metropoles, indeed into any society that even aspired to the modernity of European civilisational superiority (McClintock 1995; Young 1995; Stoler 2002). 'Race' simultaneously structures new experiences of migration, informing states' classifications of who may cross borders or settle more freely or less so, and shaping everyday experiences of belonging in old and new homes (Silverstein 2005; Yuval-Davis 2011).

Just as ethnicity has been more central than race in south-east European studies, certain migrations - those necessary to understand majority ethnic identities, their forced migrations and diasporas - have been more central than others, which do not need to be explained to tell the history of majoritarian ethnicity but are integral to understanding the place of 'race'. Indeed, even the ethnopolitical violence responsible for forced migrations within and away from the region has often involved translating ethnicity and nationhood through 'race' to more effectively dehumanise the subjects of violence and harden the symbolic boundaries of ethnic difference to their extreme. The established categories of inter-ethnic relations represent significant social realities in the region but do not account for all the migration histories in which the region has appeared. Establishing the area as a global, not just regional, 'contact zone' (Pratt 2008: 2) conversely widens the lens of which migrations might seem to be at the centre of south-east European studies (Chang and Rucker-Chang (eds) 2013), revealing connections that tie it into the global history of race.

\section{Ottoman imperial rule and transnational histories of empire}

For many historians, the centrality of migration to nation formation is what distinguishes the Balkans as a region (Mazower 2002: 53). Many south-east European national mythologies, as articulated since the nineteenth century, date ethnogenesis to the sixth to eighth centuries 
for South Slavs, or the ninth for Magyars; Greek origin myths meanwhile connect today's nation with pre-Roman city-states, Albanian myths to pre-Roman 'Illyrians' and Romanian myths either to pre-Roman 'Dacians' alone or intermingled with Roman legionaries. The shifting borders of the area's pre-Ottoman kingdoms left competing national claims to territory, history and heritage once Ottoman decline and Habsburg politics created conditions for nineteenth-century national movements to aspire to unify their nation-states.

Ottoman incorporation of south-east Europe into administrative, political and religious structures, from the late fourteenth century, shaped its migration history in many ways (Sugar 1977; Hoare 2007; Wachtel 2008). Authorities directly settled Anatolian Turkish cavalrymen on conquered land as 'timariots' who taxed local peasants and raised troops, while Ottoman trade-routes developed towns like Sarajevo and Thessaloniki into provincial capitals, refuges for many Sephardic Jews expelled from Spain in 1492. The Ottoman politics of conversion to Islam, necessary for South Slavs and other Catholic/Orthodox Christians seeking bureaucratic advancement in an empire stratifying access to power around religion not ethnicity or race, created a new Muslim South Slav ethno-religious identity among these men's descendants. 'Bosnian Muslim' identity, with South Slav linguistic heritage but Islamic religious identity/traditions, increasingly paralleled Serb (Orthodox) and Croat (Catholic) ethno-national identities during the twentieth century, even if it had first indexed a class/religion intersection; Tito's Yugoslavia institutionalised Muslim ethnicity by including it as a census 'nation' (nacija) in 1971 (Markowitz 2010: 79).

South-east Europe, peripheral in an Istanbul/Anatolia-centred empire but the frontline of Ottoman-Habsburg-Venetian imperial-territorial competition, experienced new outward migrations imposed by, or adapting to, Ottoman rule. The 'devširme'/'devşirme' system, until the mid-seventeenth century, made Balkan and Anatolian rural communities provide annual levies of Christian boys for training as an administrative and military corps loyal only to the Sultan not Anatolian nobility. These often retained links to their birthplace, like Grand Vizier 
Mehmed Paša Sokolović/Sokollu Mehmed Paša, who financed a historic bridge in his hometown Višegrad in 1577 (Kunt 1974: 235). Serb, Croat and Montenegrin national narratives, and interwar Yugoslavist novelists like Ivo Andrić, remember the devširme as a painful tool of Ottoman imperial oppression (Longinović 2011: 127-9). Another Ottoman social institution, the 'dragoman' role (interpreter-mediators for foreign embassies in Istanbul), was semi-hereditary, structured both by Ottoman elite apprenticeship practices and Venetian patrician kinship traditions (Rothman 2009: 773). Many dragomans had Greek or Albanian backgrounds, but others came from then-Venetian eastern Adriatic ports, independent Ragusa (now Dubrovnik) or Venetian Istria. Historical subjects like the dragomans are illegible to majoritarian ethnic histories but become visible through reframing history around notions such as Mary Louise Pratt's imperial 'contact zones' (Rothman 2015: 4; see Pratt 2008: 7), decentring ethnonational conflict and opening more complex connected histories of the OttomanHabsburg-Venetian past.

Some migrations caused by decades of Habsburg-Ottoman, Venetian-Ottoman and sometimes Habsburg-Venetian war (with landand sea-based raiding and banditry between wars) decisively affected long-term inter-ethnic relations. To the extent that Serb-Croat relations defined the region's twentieth-century political history (Djokić 2007), the most significant was the depopulation of the Dalmatian hinterland and central Bosnia and their repopulation through alternating integration into Habsburg and Ottoman frontier governance structures. In 1522, the Habsburg Empire first established a 'Military Frontier', under direct military administration and outside any existing province's control, along its southern border. This eventually stretched from Varaždin, in central Croatia, to today's Serbia-Hungary-Romania border in the southern Banat. Initially garrisoned by mercenaries, by 1630 it was taking most of its military strength from households of displaced Catholic and Orthodox Christians from further south. The Frontier accommodated them and their descendants as reservist-settlers, obliging men to join the Habsburg forces during war. 
The largest migration, in 1690-1, saw tens of thousands of Serbs flee Kosovo and southern Serbia when Ottoman forces retook territory the Habsburgs had temporarily held in 1686-90. Orthodox Christian settlers, often 'Vlachs' in seventeenth-century Habsburg sources, were identified and addressed by their Church and the nineteenth-century Serbian national movement as Serbs, fixing their collective identity along religious and ethnic lines. With programmes for Croat national unification (the Kingdom of Croatia, an autonomous part of Hungary, plus other Habsburg provinces inhabited by South Slavs), and wider South Slav ('Yugoslav') unification, also articulated from the 1830s-60s, the descendants of these Orthodox Christians and others would become geopolitically significant concentrated Serb minorities near Croatia's border with Bosnia and Serbia; this dispute-in-the-waiting between separate ethnonational projects could be managed or even erased by forming a Yugoslavia. This twentieth-century demographic impasse was, in longer view, a product of imperial competition.

Since these Ottoman and Habsburg projects occurred at the same time that settler colonialism and Atlantic slavery began, and European trading companies (not only the best known, like the British and Dutch East India Companies, but also those as short-lived as Courland's (Dzenovska 2013)) were expanding colonial power, a comparative history of empire might ask how far Habsburg or Ottoman imperialisms were informed by the notions fuelling Spanish, Portuguese, British, French, Dutch, Danish or Swedish colonial power overseas. Such questions, essential for decolonial longue-durée perspectives on south-east Europe, are only beginning to be pursued, with more emphasis on late Ottoman and Habsburg imperialism (Deringil 2003; Sauer 2012; Gökay and Hamourtziadou 2016) than the fifteenth to seventeenth centuries, which to Mignolo (2000) represent the origin of colonial formations of race.

Much better discussed is the Ottoman Empire's collapse and the wars to establish and expand Bulgarian, Greek, Romanian and Serbian (and eventually Albanian) nation-states, subjecting south-east Europe to the geopolitical logic of nationalism as a principle of international order (Gagnon 2004). Nationalism predicated sovereignty claims 
determining people's and places' ethnic identity, calculating majorities and minorities, and basing national borders on the resultant ethnic maps (White 2000). Before and after these nation-states gained full independence from Ottoman rule in 1878, they used churches, schools and language/naming policy to 'fix' ambiguous subjects' ethnic identity and increase their ostensible majorities against competing claims; during war and political instability, minorities could be targeted directly. The Habsburg protectorate over Bosnia-Herzegovina, agreed in the same 1878 settlement, directly expressed a European imperial 'civilising mission', with which authorities sought to temper Balkan/Muslim nationalism, backwardness and poor hygiene (Okey 2007). Discourses and technologies of imperialism circulating through the region between the 1870s and the Paris Peace Conference underlay the ethnicitynationhood-territory relationships behind ethnopolitical violence even as the region's long-term economic marginalisation as an agricultural periphery of both empires motivated hundreds of thousands of people to take advantage of the opportunities settler-colonial societies offered to migrants who - however conditionally - could be racialised as white.

\section{Ethnopolitical violence, forced migration and the racial 'Other'}

In 1878-1918 - the moment when political elites fused 'state' and 'nation' into a conjunction that still structures international politics, and the height of European identification with direct colonial mastery - Habsburg and Serbian territorial projects competed over the Yugoslav region: how far could and should the Kingdom of Serbia expand south and east, and should the Empire's South Slavs owe loyalty to Belgrade or Vienna? For Serbian political and military leaders, especially the Kingdom's longest-serving prime minister Nikola Pašić, Serbia’s historical mission was unifying all Serbs into one state. The conception of ethnicity/ territory Serbia shared with its neighbours required determining Serb territorial majorities in the present and also establishing historic Serb 
identity (often symbolised by Serbian Orthodox monasteries) for any non-Serb-majority territory the Kingdom claimed. For sociologists like Đorđe Stefanović and Dušan Bjelić, reassessing these ideologies, the biological essentialism that architects of the Serbian national programme applied to national Others (Muslims, Turks, Albanians) then used to justify their expulsion suggests European ideas of 'race' and coloniality already permeated south-east European ethnonationalism (Stefanović 2005; Bjelić 2009).

Habsburg control of Bosnia-Herzegovina, tightened through annexation in 1908, made expansion into remaining Ottoman territory more feasible for Serbia than challenging Habsburg power. Serbian forces' expulsion of 49,000 Albanians and 22,000 other Muslims in 1878 from Toplica and Kosanica (areas near Kosovo awarded to Serbia at the Congress of Berlin) showed the state did not foresee a future for Ottoman Muslim landholders, or Albanians in general, within the Serbian nation. Up to 150,000 Serbs from Ottoman-governed Kosovo and Sandžak meanwhile fled into Serbia from disorder caused by armed Albanian groups. Serb proponents of expelling Albanians, like the politician and historian Vladan Đorđević (who called Albanians both 'European Indians' and 'lazy savages' in 1913 (Stefanović 2005: 472; see also Todorova 2005b: 156-7)), thought this necessary to revert the land to an authentically 'Serb' character erased under Ottoman rule. Such ethnicisation of territory, projecting historical symbolism on to land and then expelling those who became 'minorities', could justify expansion into strategically and economically valuable territory where demography would not support the 'unification' claim (Stefanović 2005: 476).

Serbia incorporated larger territorial gains after the 1912-13 Balkan Wars even more systematically by settling veterans to farm land from which Muslims, Albanians and Bulgarians had been displaced. Post-1918 Yugoslavia, under Pašić, rolled this into its promised land reform. The Serbian and Yugoslav states, and at least more ideologically committed settlers, viewed this as 'strengthening the national element' of liberated land; it could simultaneously be called 'internal colonization' through settlement (Newman 2015: 92-3), and Albanians readily identified their 
situation with other colonised peoples' (Malcolm 1998: xlvi). Figures like Đorđević casting Albanians as threats to Serbs in Kosovo evoked tropes of savagery and tribalism, identifying Serbs in the Balkans with white Europeans in America and Africa by suggesting they enjoyed civilisational superiority over yet were threatened by the subordinate Albanians. The Serbian academician Vasa Čubrilović, directly arguing for 'the expulsion of the Albanians' ('isterivanje Arnauta') in 1937, both advocated ethnopolitical separation and exemplified 'colonizing projects' that aligned Serbs (and maybe other Christian Yugoslavs) with the colonial Europeanness and whiteness of the former protectorates over Bosnia and Albania (Rexhepi 2016: 148), even as balkanist discourses made Serbs 'Others' to 'Europe'.

Viewing the 'colonisation' programme through an ethnopolitical conflict lens emphasises questions of territory, identity, aggression and victimhood. Among these are whether its expansionism should be considered aggression; how many non-Serbs were directly displaced through violence by Serbian forces and self-organised paramilitaries; ${ }^{2}$ whether Serbia/Yugoslavia could legitimately settle Serb farmers on such lands; how well founded were competing Bulgarian/Macedonian/ Albanian ethnonational claims; and how direct was continuity between this Serbian programme or its supporters' xenophobia with eliminationist positions in Serb political discourse during the 1990s. Comparative European history would place south-east European national expansionism within the same norms by which Piedmont and Prussia justified wars of national (Italian/German) unification in the 1860s-70s. ${ }^{3}$ South-east European ethnopolitics and European geopolitics, however, both existed within a deeper framework of global coloniality in a fin-de-siècle when, Dušan Bjelić (2009: 286) observes, south-east European intellectual elites routinely attended the universities of their 'geopolitical allies'. European colonial imagination directly entered south-east European politics through these routes, translated through whatever identified one's own nation with 'Europe'.

Bjelić, indeed, arguably does most to set early-twentieth-century south-east European politics of identity in global not just European 
context. Bjelić's work on First World War colonial soldiers, often used in roles with even higher death-rates than white European troops', leads him to argue that a 'racial genealogy' of the Great War ought to replace the 'national paradigm' in European First World War histories that has erased the 'constitutive violence' of bringing almost a million black and Asian colonial soldiers to fight on European fronts (Bjelić 2014); this involved not just the Western Front but others, including the Salonika Front, where French African divisions fought in autumn 1918 (Bjelić 2016). Elsewhere, researching emigration from south-east Europe beyond the most-studied destinations of Europe and the Anglosphere, he traces Bulgarian Zionists' participation in colonising Palestine to directly connect - not just compare/contrast - south-east European history and the colonial history of the Middle East (Bjelić 2017). Prevailing approaches in the region's historiography could not even frame the question of where the Serbian national project or Yugoslav unification would fit into a 'racial genealogy' of the First World War - and yet the black soldiers on the Salonika Front, even alone, would show the region was not outside that genealogy (Bjelić 2016). The Great War is as much a part of the history of race and the Yugoslav region as the theme on which the most explicit discussions of race in the region have turned - the racialisation of ethnonational and religious boundaries that facilitated genocidal expressions of Serb and Croat ethnonationalism during the Second World War.

\section{Scientific racism and ethnonationalism before and during the Second World War}

Interwar Yugoslavia, more than any other period, saw national identity construction in the Yugoslav region dependent on explicitly as well as implicitly evoking 'race'. This Yugoslavia's identity was caught between Serb/Croat/Slovene ethnopolitical identities separate enough to be included (until 1929) in the unified Kingdom's first official name and the state's need for a unifying collective ideology around 'South Slav' 
ethno-linguistic commonalities (Albanians and other non-South Slavs were beyond the nation-state's majority community). 'Race' itself, and 'racial theory' dividing the world's peoples into named races with identifiable physical characteristics and equally immutable psychological ones, were demonstrably known in interwar Yugoslavia within the context of European scientific racism (Bartulin 2009), just as in neighbouring Bulgaria (Todorova 2006) and, indeed, in the US ethno-cartographic inquiry into south-east Europe that informed negotiations at the 1919-20 Paris Peace Conference (Crampton 2006). In Yugoslavia, however, race did not just signify the majority nation's global position but also mediated how separate South Slav identities related to overarching 'Yugoslav' identity.

Ideas of unifying all South Slavs (not just Serbs) had existed since the 1830s, in tension with Serbian unification and several different Habsburg approaches to the 'South Slav question' (Djokić (ed.) 2003). ${ }^{4}$ Throughout the First World War, Pašić and Habsburg South Slav leaders had quarrelled over the constitutional balance between Serbs and other South Slavs, and Serbian and Habsburg state structures. After December 1918, when 'National Councils' in Zagreb and independent Montenegro unified with Serbia, the 'Yugoslav idea' - whatever it meant - had to become not only a concrete constitutional settlement but also an ideology of national cultural expression (Wachtel 1998).

The 'Dinaric race' named by the interwar Yugoslav anthropologist Vladimir Dvorniković in 1939 mediated these contradictions, Tomislav Longinović (2011) argues, through a culturalist definition of Yugoslav identity that distanced Yugoslavs, as a recently liberated nation, from imperial modernities. The Dinaric highland place-myth, and an ethnological imagination centred on Bosnia/southern Serbia/ Macedonia, allowed Dvorniković to term South Slavs one 'Dinaric race. This shared experiences of domination by foreign empires (not dominating other peoples) and a melancholic mentality expressed through Bosnian, southern Serbian and Macedonian - but explicitly not Roma - folk-song; it encompassed groups that ethnonational Serb/ Muslim or (if Croats could accommodate Dinaric Balkanness) Serb/ 
Croat antagonisms separated. And yet 'non-Slavic peoples', including Albanians, Roma and Jews, only appeared 'as a negative against which the Slavic folk genius had been imagined' (Longinović 2011: 101). Even in its own terms, this historically subordinated, now-liberated Yugoslav race contained a racialised hierarchy, one of many intraEuropean racism[s]' (Robinson 1983: 67; Jahoda 2009) in anthropology at the time.

Interwar Yugoslav adaptations of scientific racism and eugenics indeed linked biological racial essentialism to existing Yugoslav ethnonational identity hierarchies. One Serbian doctor, Svetislav Stefanović, purported he could differentiate the peoples of 'Europe' from 'African and Asian peoples' by blood-type, that inhabitants of Yugoslav regions 'where ... the forces of state creation have been most prominent' (Serbia, Montenegro, the Adriatic coast) had 'the highest European blood index', and that 'the higher degree of mixture between foreign racial qualities' produced lower European blood indices in Croatia, Slovenia and Bosnia (Petrović (ed.) 2015: 508). ${ }^{5}$ His racial thinking clearly suggested Serb political and cultural superiority over other South Slavs, implicitly justifying Serb predominance in Yugoslavia: scientific racism was thus applied to ethnonational differences between South Slavs even as it became a foundation for antiziganism and anti-Semitism.

Yugoslav anti-Semitism, as elsewhere, involved notions of 'race' that, even if 'unclear' (Sekelj 1988: 160), still strictly separated majorities from Jews. Croat students in Zagreb first demanded a maximum quota (numerus clausus) of Jewish students in 1920, when Hungary passed one; such demands intensified in Croatia's 1930s Catholic press, while other theologians like Andrija Živković denounced racism (Živković in 1938 condemned 'racists [who] consider the interests of race and blood ... the measure of good and evil' (Goldstein 2003: 122-5)). The last Yugoslav government before the Axis invasion introduced a numerus clausus, and banned Jewish military officers reaching high ranks, in 1940; the governor of Croatia, granted extensive autonomy in 1939, refused to implement it, arguing it interfered with Croatia's autonomy in education (Sekelj 1988: 169). 
In March-April 1941, the Axis occupied Yugoslavia, installing puppet regimes in an enlarged Croatia and rump Serbia; both applied ideologies of racial purity, anti-Semitism and eugenics to the ethnic nation. Milan Nedićs 'Government of National Salvation', formed at Wehrmacht invitation in August 1941, established a 'Committee for the Protection of Serbian Blood' to pass eugenics laws for national cultural regeneration (Ramet and Lazić 2011: 28); its commander of paramilitary volunteers, Dimitrije Ljotić, had founded the fascist movement Zbor in 1935 and believed Jews, Bolsheviks, Freemasons and Western capitalists were conspiring 'to subjugate the "white" race', including Serbs (Sekelj 1988: 167). The 'Independent State of Croatia' (NDH), in power between April 1941 and May 1945, had even longer to implement its ideology, collaborating with the Nazi extermination of Jews and organising its own genocide against Jews, Roma and Serbs.

$\mathrm{NDH}$ ideology derived from the Ustaše ('Insurgents'), the Croat revolutionary-fascist movement founded in 1928 by Ante Pavelić, 'Poglavnik' ('Duce'/'Führer') of the NDH. It looked back to the nineteenthcentury writer Ante Starčević, who (against emerging Yugoslavism) had believed Serbs, after long servitude under the Ottomans, lacked Croats' cultural advancement and state-building capacity. Croat nationalists of the 1920s had used racialised categories to posit Croats and Serbs had different histories of ethnic mixing (Serbs intermarrying more with Vlachs and Roma, Croats having more Nordic and Aryan blood) and oppose the unitarist idea of Yugoslavs as a homogenous race (Bartulin 2008: 84-5). Pavelić went further, arguing that Croats were not even Slavs but had separate Iranian, and therefore Aryan, descent (Bartulin 2008: 88). NDH racial laws, closely following German and Italian models (including a 'Law on the Protection of the Aryan Blood and Honour of the Croat People'), based membership of the national community on being 'Aryan', that is, 'having ancestors who were members of the European racial community or who descend from branches of that community outside Europe' (Blažević and Alijagić 2010: 905-6).

$\mathrm{NDH}$ racial ideology specified Jews and Roma as non-Aryan (Biondich 2002: 34), treated Bosnian Muslims as Aryans and Islamicised 
Croats (Kisić-Kolanović 2015), and ostensibly offered Orthodox Serbs conditional belonging if they became Catholic yet in practice directed 'racial purification' against Serbs, Jews and Roma alike (Yeomans 2015: 22). Serbs, while not non-Aryan to the NDH (it classified them religiously as 'grčkoistočnjački' or 'Greek-Eastern'), were 'portrayed as ... racially similar to Jews and Gypsies' because of miscegenation, and many discriminatory decrees still targeted them (Bartulin 2008: 91-3). NDH anti-Communist propaganda was also racialised: one 1944 pamphlet warned of 'the hordes of ... the dark, uncultured barbarian East, that have today rushed towards Europe', and described Soviet soldiers behaving with Croat prisoners' keepsakes 'as if they were wild black men' (Erdeljac 2015: 78). The 'Ustaša terror' against Jews, Roma and Serbs, beginning with property confiscation and revocations of civil rights, became a mass extermination programme that claimed the lives of more than 75 per cent of Jews, 'and probably an equivalent proportion of the Roma', in the NDH (Dulić 2006: 273). More than half the victims at the NDH concentration camp at Jasenovac, opened in August 1941, were Serbs (Kolstø 2011: 225); indeed, the NDH's first interior minister, Andrija Artuković, reportedly said the Ustaše 'had killed the black Gypsies [Roma], and all that was left was to kill the white Gypsies [Serbs]' (Reinhartz 1999: 86), indicating this genocidal ideology's racialised slippages.

While most studies of the NDH imply it imported racial theory from Nazi Germany, the historian Nevenko Bartulin argues racial theory was a Croatian and Yugoslav, not just a German, phenomenon: NDH ideologues also knew how interwar struggles over South Slav ethnopolitical identities had been framed around race by adapting German scientific racism (Bartulin 2013, 2014). ${ }^{7}$ Hans Günther's six physically distinguishable European racial subgroups had included a 'Dinaric' race (alongside Nordic, Mediterranean, Alpine, East Baltic and Phalian) on which definitions of Yugoslav and single-nation identities would draw (Bartulin 2009: 199-213). ${ }^{8}$ The NDH defined its ideal Croat as a 'Nordic-Dinaric' racial type, tall, fair-haired warrior heroes from the Croatian/Bosnian highlands, and accommodated Muslims by arguing that Islamicisation 
had not diluted their bloodline, Croatian language, or fair skin and hair (Kisić-Kolanović 2015: 194-5). Interwar and wartime Croatian ethnic belonging discourses contained transnational racial formations that historians would miss if they conflated race and ethnicity completely. For Gilroy, meanwhile, Pavelić's myth of 'descent from heroic Aryan sources' alongside the primordialist colonial separation of Hutu/Tutsi identities in Rwanda shows ' $t$ ] he specific force of modern racist discourse' (Gilroy 2000: 300; emphasis original) carried well beyond western Europe, where fascism is most studied. Reading Bartulin and Gilroy together emphasises the adaptive formation of race in Second World War Croatia, appropriating transnational racial formations into eliminatory ethnicised nationalism. These exclusionary identity discourses acquire fresh global contexts in a transnational history of 'race'; yet so do the discourses of mixing and hybridity, often held up in south-east European identity discourses as the opposite of ethnonationalism, which became an ingredient of post-1945 regional identities in the Eastern Adriatic.

\section{Ethnicity and the silences of 'hybridity' in Istria}

Within literature on ethnicity in the Yugoslav region, Istrian regional identities, with their historical narratives of everyday multilingualism and Italian-Yugoslav/Italian-Slovenian-Croatian border-crossing, often exemplify multi-ethnic alternatives to ethnonationalism. Both the inhabitants of ex-Habsburg Trieste, assigned to Italy in 1945-54, and post-Yugoslav residents of Croatian Istria resisting state-level ethnicised homogeneity in the 1990s (Kalapoš 2002; Bellamy 2003), imagined Istria as historically 'hybrid' - allowing Homi Bhabha's work on identity and hybridity (see Bhabha 1994) to be translated into theories of southeast European ethnicity - and cosmopolitan. Yet both narratives, the anthropologist Pamela Ballinger (2004) argued, still depended on essentialised ideas of ethnicity-modernity-territory. While Trieste's own identity myth still concealed earlier Venetian, irredentist and Fascist perceptions of Slavs as less modern, the myth of 'successful ... ethnic 
convivenza' in post-Yugoslav Istrian regionalism also reflected a 'nesting orientalism' (Bakić-Hayden 1995) contrasting Istrians against nationalistic, violent Balkan peoples (including other Croats) responsible for the wars (Ballinger 2004: 36, 41-2). Moreover, 'authentic' Istrian hybridity still seemed not to accommodate 'nonautochthonous' residents (Ballinger 2004: 42) - including the Croatian, Bosnians and Albanian migrants Ballinger mentioned, and indeed racialised migrants from outside Europe who, in smaller numbers, belonged to Istrian social reality as well. Deep in the silences of Istrianity, did Istria's admixture of Italian heritage and even blood supposedly explain its differences?

Ballinger's deconstruction of Istrian place-myths contributes to the history of racisms in Europe from the often-neglected perspective of ethnicities in the eastern Adriatic - by proposing Triestine exiles' post-1943-5 racialisation of 'Slavo-Communists' as an antecedent of ' $\mathrm{t}$ ] he elision of biologically ascribed race and culturally given national identity' in late-twentieth-century European cultural racism (Ballinger 2004: 36). Her warning not to romanticise hybridity uses postcolonial scholars including Gilroy, Robert Young and Anne McClintock to suggest that, if ideas of hybridity still depended on historic ideas of mixture, purity and race, Istrian hybridity discourse still possessed 'an inherent link to the very categories of classification that it claims to oppose' (Ballinger 2004: 34). Indeed, echoing Said's reservations about 'traveling theory', Ballinger also perceived a parallel with 'elite appropriations' of hybridity and mestizaje critiqued by anthropologists like Charles Hale (1999) in Guatemala and elsewhere (Ballinger 2004: 49).

The Ballinger-Hale reading of mestizaje was closer to some Latin American states' hegemonic nation-building ideology (Wade 2004) than the counter-hegemonic postcolonial and intersectional consciousness built by Chicana feminists and other feminists of colour around mestizaje's meaning to Gloria Anzaldúa (Tuhkanen 2009; Collins and Bilge 2016: 71-2). Anzaldúa's expression of a working-class Chicana lesbian consciousness, within global racial formations, inhabited a different race/ class/sexuality intersection to anti-black elite 'whitening' of nationhood in Mexico or Brazil (Goldberg 2009: 218-36). Her balance between 
marginality and essentialisation - locating 'every identity ... in a culture, a language, a history' and naming their junctions - invites a 'politics of articulation' (Yarbro-Bejarano 1994: 10) that helps theory not just to travel but to connect. Such a connection for Istrian hybridity and Chicana mestizaje might ask: where is the Italo-Yugoslav borderland, as a legacy of Italian irredentism and South Slav nation-building, in relation to the US-Mexico borderland as a legacy of settler colonialism? Anna Agathangelou (2004a), in postcolonial and feminist International Relations, comes closest, reading the militarisation of the US-Mexico border and post-Yugoslav women's mobilisation in support of 1990s ethnonational wars as two facets of the transnational reconstruction of a capitalist patriarchy - a deeper superstructure behind both 'contact zones', in which even the internal migrations of socialist Yugoslavia deserve to be linked to global dynamics of border control and class.

\section{Social inequalities and migration during and after state socialism}

Extensive internal migration in socialist Yugoslavia, where hundreds of thousands of people moved in the 1950s-60s from rural/highland regions to urban centres for factory work or towards more fertile agricultural land, took place in a structure of property ownership shaped by the expropriations of the Holocaust, the Ustaša terror and the Communist expulsion of Germans in 1945, just as earlier settlements of Serb farmers in southern Serbia, Macedonia and Kosovo had been intrinsically linked to displacements of Albanians and South Slav Muslims. This migration - from the poorest south-eastern republics to the richest north-western ones, but also within republics from peripheries to centres - affected both urban and national identities. In large cities, established urban social strata complained new city-dwellers were bringing village mentalities into the metropolis, intensifying the 'urban/rural' clash in European-versus-Balkan hierarchies of modernity. Between Yugoslav republics, inhabitants of Slovenia and Croatia in particular perceived 
levels of cultural difference within their cities increasing (Dragićević-Šešić 1994; Archer, Duda and Stubbs 2016). The internal migrants most exposed to racialised practices of Othering that resembled Western European cultural racism were Albanians and Roma.

Albanians and Roma experienced similar, but not identical, marginalisations in socialist Yugoslavia. Security-minded state institutions viewed Albanians as a subversive minority because their ethnic kin-state, Albania, had a rival territorial claim; Roma suffered from their identity having no 'homeland' attached at all (McGarry 2017). During the Yugoslav wars, this would leave Roma caught 'in between' programmes of ethnopolitical violence in a way that, for Julija Sardelić (2015: 163), makes Bhabha's 'in-betweenness' more appropriate than 'Othering' to describe their position. Socialist Yugoslav media were ambivalent about whether Roma were a social underclass or an ethnic minority - but in agreeing that Roma were marginalised because of their own backwardness, they still made arguments that resembled Western European cultural racism, showing those discourses did not just appear as part of a postsocialist resurgence of nationalism (Sardelić 2016: 102). Albanians in the late 1980s, meanwhile, were simultaneously labelled as fundamentalist Muslims in Serb nationalist media and treated as a semi-racialised, culturally and ethnically distinct underclass in Slovenia and Croatia.

These articulations of socio-economic inequality and ethnicised difference all allowed long-standing balkanist discourses of separating the national self from Ottoman cultural space to fuse with identification with late-twentieth-century meanings of 'Europe' informed by transnational cultural racism (Mihelj 2005; Longinović 2011; Sardelić 2016). The presence of 'race', in many facets, within the Yugoslav region's history of ethnicity puts the region within global formations of whiteness, 'Europeanness' and modernity well before the 1990s. And yet even broadening the history of ethnicity is not enough: migrations that do not fit this dominant theme so easily, and that are often therefore neglected, reveal a global past and present where encounters with blackness, indigeneity and other racialised constructions of difference ground the Yugoslav region even more tightly in transnational formations of race. 


\section{Microhistories of race and empire: the 'blacks of Ulcinj' and the explorers of Karlovac}

Calls for globalised 'connected histories' of race, gender and empire, using lenses such as microhistory, translocality and intimate politics (Subrahmanyam 1997; Ballantyne and Burton (eds) 2005; Burton 2007; Bhambra 2014: 4; Potter and Saha 2015), suggest that quantitatively small migrations still reveal important underlying connections between regions. One such, for south-east Europe, is the history of biracial AfroMontenegrin/Afro-Albanian families in Ulcinj, occasionally 'rediscovered' by anthropologists and journalists since the mid-twentieth century. A legacy of Ulcinj's place as a node in the Eastern Mediterranean slave trade, this migration probably involved fewer than a hundred households, but is evidence of a literal 'Black Adriatic': that is, the Adriatic just like the Atlantic is indeed a direct site of African diasporic history. ${ }^{9}$

Ulcinj, conquered by Montenegro from the Ottoman Empire in 1878, did not have as large a role as Tripoli or Benghazi in the Eastern Mediterranean slave trade, which 'affected the entire geography of Africa' while transporting slaves to south-east Europe and the Caucasus (Fikes and Lemon 2002: 498). A subsidiary slave port under Ottoman rule, it remained implicated in enslavement of Africans when Ulcinj-based merchant captains brought back slaves they had bought at sea for their own households or for sale to others. Although a few (Albanian) captains emigrated in 1878, at least two captains (Tahir Šurla and Hasan Šepeteja) at the beginning of the twentieth century still brought slaves to Ulcinj. These slaves had been captured aged 'from two to three up to 16 years old' (Lopashich 1958: 169) in Sudan, perhaps in Bagirmi, then taken along established caravan routes to North African ports. Aboard ship, they were given their captains' surnames, though many also acquired the surname 'Arap' (Turkish, Serbo-Croatian and Albanian for 'Arab'). Ulcinj might have had a hundred black families in the earlier nineteenth century (Lopashich 1958: 169), but this had declined to approximately fifty families (150 people) by 1878 . Enslaved Africans in Ulcinj could marry each other but nobody else, though once freed some married 
into local Albanian and Montenegrin families, founding Ulcinj's small biracial community (Canka 2013). ${ }^{10}$

The anthropologist Alexander Lopašić, visiting Ulcinj in 1956, viewed this community through a racialising European ethnographic gaze. One family, he wrote, 'have retained their racial characteristics, a very dark and almost black skin, the typical curly hair, thick lips and physical strength'; another man 'possesses all the Negro characteristics, but his skin is somewhat lighter and he has an elongated skull' (Lopashich 1958: 173). Lopašić also recorded several family trees, and songs/dances with likely Arab or Bagirmi origins. His essentialised account of the 'Negroes' temperament was consistent with European and colonial formations of blackness:

Though known for their kindheartedness, they were also much feared when in a bad temper ... In spite of the new environment and a different social atmosphere, the Ulcinj Negroes succeeded in retaining some of their characteristics, such as lightheartedness, fondness of music, rhythm and fun, love of family life and a certain amount of personal attractiveness. (Lopashich 1958: 171)

Beyond acknowledging a movement of people and capital so marginalised in most Montenegrin/Yugoslav history as to be invisible, this said very little about the Africans' experiences of enslavement, or their visibly racialised descendants' experiences.

Another Yugoslav anthropologist, Đurđica Petrović (1972), and several Yugoslav/Montegrin journalists, have revisited the history of black families (often condensed to the Šurla family) in Ulcinj. In 1986, the photographer Rizo Šurla (who had been born in 1922, fought as a Partisan in the Second World War and joined the League of Communists (SKJ) in 1959) described life as a black man in Yugoslavia to RTV Revija in terms identifying with Yugoslavia's geopolitical position:

I've never had any problems. I've always felt like a Yugoslav, a Montenegrin, I was born here, in this multi-national community [...] Our country is, 
in terms of equality, probably unique in the world and I'm proud to have been born in it and live in it. [...]

Unfortunately, I've never been to Africa, my ancestors' birthplace, and I don't know what it's like there, but from what I've seen on television or in films - I don't think I could live there.

Look what's happening in South Africa.

I believe that many Blacks would envy me if they knew what kind of country I lived in. (Predić 1986)

This imagined Yugoslavia - unlike South Africa, a year into its state of emergency - was free from both racial prejudice and racialised/ethnicised violence, something Communists had consistently feared. ${ }^{11}$ Šurla even narrated his own biography into the Communist state-building narrative: according to his war story, a well-known Montenegrin Partisan, Mitar Bakić, asked his identity during a parade. When Šurla answered, 'I am a fighter, a Partisan, Rizo Šurla, a Montenegrin from Ulcinj', Bakić apparently replied in dialect, 'I know we Montenegrins are black, but, brother, you're really pushing it! [ti ga, brate, prećera!]' (Predić 1986). The anecdote remained in the family - though the commander became another Montenegrin general, Savo Burić - when the Montenegrin newspaper Vijesti interviewed Šurla's son and grandson in 2013 (here, Burić supposedly said 'God, I knew we were black, but not like this!'). Vijesti also drew on Lopašić and Petrović's anthropological writing to describe the community's assimilation into Ulcinj:

Ethnologists have also stated the blacks of Ulcinj [ulcinjski crnci] were well-built and powerful people, brave and bold. However, children from mixed marriages, as Petrović writes, had softer [ublažene] physical characteristics of blacks as well as lighter skin tone. Despite their new environment and living conditions, they retained their authentic characteristics such as lightheartedness, fondness of music, rhythm and fun, and love of family life. (Adrović 2013)

Indeed, the end of the extract from Vijesti follows Lopašić so closely that the racialising gaze of a British anthropological journal and Viennese-trained anthropologist in 1958 could still be reproduced 
in 2013, indeed more than in 1986 - except that the 'certain amount of personal attractiveness' with which Lopašić eroticised his subjects had disappeared.

Behind Ulcinj's local narratives are multiple dimensions of raciality, from the very question of Montenegrins' relationships to 'blackness' (South Slav languages, and Italian, all call Montenegro 'Black Mountain') to the longer history of Eastern Adriatic/Mediterranean slavery. In the early Middle Ages, Slavs from the coast and hinterland were enslaved and sold in the Middle East, North Africa, northern Italy and Spain, with Korčula and especially Dubrovnik as hubs. Europeans' direct enslavement of Africans from the mid-fifteenth century (forcing them to work sugar plantations in Madeira and the Canary Islands even before the colonisation of the Americas) reoriented Mediterranean slavery so that '[i]n Ragusa, where so many Slavs had been collected and registered for sale beyond the seas, now black "Slavs" arrived from beyond the seas' (Evans 1985: 52-3). This line, undeveloped in a conclusion yet implicating an Adriatic port directly in European domination of Africa, points to an article on 'Black slaves in old Dubrovnik (1400-1600)' by the historian Vuk Vinaver in the Belgrade Historical Institute's journal, Istorijski časopiš, in 1955. These connections are not completely unresearched; but rarely are they carried forward.

Based on the etymology of 'Slav' and the history of the region's national movements resisting imperial rule, some South Slavs have suggested a shared history of enslavement could be a basis for fraternity between Africans and Slavs (Jović Humphrey 2014: 1137-8). This direct equation of blackness/Balkanness, not unlike Yugoslav Non-Aligned identification with anti-colonialism, mediates some identifications with Africa in (post-)Yugoslav arts and culture. However, although the history of chattel slavery and transnational anti-blackness has occurred on the same globe and within the same networks of ideology and capital as the history of Eastern Mediterranean slavery and the marginalisation (sometimes amounting to racialisation) of the Balkans, they are still not reducible to each other. Moreover, the Yugoslav region's history of enslavement and coloniality would also include South Slavs' involvement in structures of European colonial rule: although the Habsburg Empire 
did not extend overseas, inhabitants of its lands - including South Slavs - still participated in other European countries' imperial projects.

The histories of South Slav explorers and colonial officials are told primarily through investigating collections of papers and objects they brought home. The town of Karlovac connected several late-nineteenthcentury Croatian travellers to Africa, such as the cartographers Mirko and Stevo Seljan (who assisted Emperor Menelik II in Ethiopia during the late 1890s, and later helped map the Amazon) and the explorer Dragutin Lerman, who joined the Stanley expedition to Congo in 1882 and spent ten of the next fourteen years as a Belgian provincial official there (Kočevar 2012). The Seljans, Lerman and another Karlovac man who accompanied him (Janko Mikić-Bojkamenski) were all subjects of a 2013 exhibition on 'Karlovčani in Africa', curated by Sanda Kočevar, at the Karlovac City Museum. A Rijeka-based historical geographer, Mirela Slukan-Altić, has published several book chapters on the Seljans, Mikić and Croatian missionaries in Spain's Spanish colonisation of the Americas (Slukan-Altić 2003, 2008, 2012). ${ }^{12}$ Yugoslav anthropologists researched some of these figures in the 1970s (Lopašić 1971; Lazarević 1975), with a collaborative article on Slovene, Croat and Serb explorers in Africa possibly the most complete overview (Šmitek, Lazarević and Petrović 1993) - but, published in French during the Yugoslav wars, it was unlikely to inspire a new direction for Yugoslav history.

The Karlovac explorers' mobilities show that South Slavs, as aspiring imperial subjects, could participate in exercising European colonial power and domination. If these are not grounds for collective guilt, neither can they be grounds for collective exculpation. Indeed, life histories from the region were entangled with global histories of empire and race well before the nineteenth century. Even if, like Mignolo (2000, 2008; Greer, Mignolo and Quilligan 2007), one traces 'race' to Spanish theologians' classifications of civilised and savage peoples during the conquest of the Americas, here too the region is present: we find the Korčulan-born Dominican, Vinko Paletin or Vicente Palatino/Paletino (1508-73), whose writings justified Spanish warfare against the 'Indians' in 1557-8 and rejected Bartolomé de las Casas's case for peaceful 
conversion (Hanke 1964: 294). Paletin, raised in the Venetian Adriatic when Ottoman-Venetian proxy warfare through piracy and banditry was at its height around islands like Korčula, had himself sailed and fought in Francisco de Montejo's 1535-41 conquest of the Yucatán (Bošković 1997: 202-3). One can only speculate how the younger or older Paletin translated his observations of Indians and the Americas through his knowledge of Adriatic warfare; but if the Yugoslav region is written, as it should be, into the European 'republic of letters' (Bracewell 2011), it cannot be written out of the coloniality that permeated that republic, as contested as the region's status within 'Europe' remained. The region's past interconnected histories of raciality thus turn new lenses on migrations in the present.

\section{Postsocialist, post-conflict and postcolonial migrations}

Migrations into the region, compared with migrations around or out, are marginal for most studies of the present-day Yugoslav region, even those that already join two explanatory paradigms by accounting for social inequalities as well as ethnicised conflicts. By the late 1990s, however, Slovenian polemics over 'asylum-seekers' (Mihelj 2004; see Chapter 4) were already showing that the post-Yugoslav region was not only a migration origin-point but also a destination. While most migrants were outside local categories of ethnic difference, many (through combinations of skin colour, religion, nationality and economic marginality) fell into local categories of racialised Otherness, with specific locations in the postsocialist/post-conflict economy.

One distinctive pattern of postsocialist/post-conflict inward migration has involved the travel of women from post-Soviet states as sex-workers, whose clients and sometimes even traffickers include the extensive foreign military and civilian workforce of international intervention in Bosnia-Herzegovina and Kosovo. These circuits, including (but not solely) coercive operations by organised criminals and some private security contractors, are global networks connecting sex-workers' home 
countries with south-east Europe and other zones of neoliberal enclosure such as the Emirates' spectacular hubs of capital and south-east Asian cities' business districts (Harrington 2005; Suchland 2015). Many postSoviet sex-workers are fair-skinned, and the blonde, Russian, passionate 'Natasha' stereotype is a vector of desire (Gülçür and İlkkaracan 2002: 414). Their socio-economic marginality and the marginality of eastern Europe/Russia in 'Western' imaginations produces a racialised, exoticised category that Anna Agathangelou (2004b: 88) (after research in Cyprus) calls 'white but not quite', subordinated and available for exploitation by Western men and as exoticised 'object[s] of ultimate masculine "desire"'. Ethnic-majority members in Cyprus, Greece and Turkey can assert their group's own Europeanness and whiteness, in the face of semi-racialised formations projected by the West on to the post-Ottoman space, by signalling these women's marginality (Gülçür and İlkkaracan 2002; Agathangelou 2004b). The post-Yugoslav trope of the post-Soviet sex-worker, constructed as symbols of postsocialist crisis, might within the semi-racialised formations of Othering and balkanism projected across the post-Ottoman space facilitate a similar assertion.

Another 'symbolic' postsocialist migration involves Chinese traders. Many 'Chinese shops' ('kineške prodavnice') have opened since the mid-1990s selling cheap clothing and household goods from storefronts that closed during the wars, or marketplaces or urban peripheries like New Belgrade's 'Blok 70'. These have represented a new form of visible racialised difference in urban space and, for many post-Yugoslavs, another symbol in public discourse of how the collapse of socialism has altered life and the economy beyond recognition - while adding a new stereotype to how 'Chinese' is racialised (Blagojević 2009). Beyond urban myths in Milošević-era Belgrade, implausibly holding that Milošević offered tens of thousands of Chinese migrants visa-free residency in return for votes before the contested 1996 election - when Serbia did liberalise its visa regime with China to encourage investment (Korać 2013a: 229) - Chinese migration into Serbia and other post-Yugoslav states is just one dimension of a globalised economic expansion into economically depressed areas (including West Africa) that Western investors have 
not prioritised (Chang 2013b: 138-9). Felix Chang and Sunnie RuckerChang's 2013 edited volume on Chinese migration in Russia, Central Asia and eastern Europe is one of few studies of postsocialism with racialised migrants at the centre, not the margins. The very concept of 'Chinese migrants', Chang establishes, in fact hides many positions within the formal and informal economy, plus much more specific translocal dynamics of economic chain migration (Chang 2013b: 142). ${ }^{13}$

Chang's difficulties obtaining official data about Chinese migration (beyond those of counting undocumented migrants and those who do not interact with census-taking) indicate statistical practices in Serbia and other post-Yugoslav states are more geared towards existing frames of ethnopolitics rather than recording new multicultural and multiracial categories in society: Serbia's Chinese population, estimated by Chang at 20,000-30,000 - similar to recorded numbers of Macedonians $(25,847)$ or Bulgarians $(20,497)$, and larger than the traditional Slovene, Ukrainian or Czech minorities of 2,000-5,000 - was invisible within the twenty-two categories of 'national belonging' or ethnic identity inherited from Yugoslavia (Chang 2013a: 155-6). The Department of Foreigners, which collected passport nationality data, meanwhile recorded 4,947 Chinese nationals in 2009 (Korać 2013b: 247) - while Serbian media quoted up to 100,000 (Blagojević 2009: 48). This statistical lack arguably prevented Chinese litigants proving that police demanded bribes more often from them than Serbian traders, since they would have had to rely on enforcement figures which were not broken down into specific enough ethnic or racial categories to prove disparate treatment of Chinese traders as a group (Chang 2013a: 169-76). Race was even more invisible beyond categories of historic ethnopolitical territorial competition in BosniaHerzegovina. ${ }^{14}$ There, the Dayton Peace Agreement of December 1995 jettisoned most Yugoslav ethnonational categories, a post-war reduction of ethnic complexity to the Bosniak-Serb-Croat triangle. The state thus only collected data on these three categories plus 'Others', not even the country's largest minorities of Jews or Roma (Markowitz 2010). ${ }^{15}$

Chinese presence is, however, recognised in post-Yugoslav film (Rucker-Chang 2013). In particular, the early-2000s wave of Slovenian, 
Croatian, Bosnian and Serbian films framed as commentaries on the extent of post-Yugoslav socio-economic change often contained storylines about Chinese traders, restaurateurs and undocumented migrants. Only in Serbia, however, did film-makers represent their country as the destination not the transit point. The other films, with plots about human trafficking, used Chinese migrants as a device to illustrate Slovenian hierarchies of xenophobia (with Middle Eastern and Chinese migrants more external and less knowable 'Others' than ex-Yugoslav migrants); to dramatise Croatian small-town intolerance (towards a single mother's biracial white/Chinese child) as a departure from idealised European values, albeit one that needs the audience to share a 'visceral reaction' to the child's visible difference; or to comment on post-war Bosnia's lack of future (Rucker-Chang 2013: 205, 210) - all, in other words, to be 'a proxy for unrecognizable change' in narratives about post-Yugoslav 'transition' while still appearing 'wholly outside the historically defined Other' (Rucker-Chang 2013: 201; emphasis added) of Roma, Jews and ethnonational enemies. Post-Yugoslav public culture makes Chinese and other racialised migrants symbols not subjects of postsocialism - whereas migrants from the region remain protagonists of post-Yugoslav studies even on the far side of the globe.

\section{Confronting race and whiteness in diaspora}

The Yugoslav region's worldwide diaspora communities, whether place-of-origin-based ('zavičajni'), ethnonational or (post-)Yugoslav, encounter destination countries' formations of race and whiteness even as they reconfigure identities they know. Some destinations, like the USA, have unmissable, everyday racial politics, where migrants must try to understand the balance of interracial relations and determine how they, individually and collectively, might desire to be racialised or are racialised by others. In others (like Sweden or the Netherlands), where the historical whiteness of national identity is so hegemonic that - for white people - racial politics are less perceptible, late-twentieth-century 
migrants were caught between identifications with Europeanness and whiteness that might have been common sense in Yugoslavia and cultural racism in the majority nation that might classify them, alongside Somalis, Rwandans and others fleeing 1990s conflict zones, as social problems. The migration of Roma, racialised into a specific category in Europe while subject to more diffuse discrimination in the USA, is an even more complex translation of individual experiences of racialisation along transnational migration routes - yet if race is an undeniable category of analysis for Romani migration, so is it for the region's ethnic majorities.

Bulgarian and Macedonian Roma in the US, for instance, often discover that stigmatised markers of Romani identity in south-east Europe are either less recognisable as Romani in the US (language, dress, skin colour) or do not exist because of different settlement patterns (Silverman 2012): the racialised categories for differentiating US urban districts do not include 'Romani', while in south-east Europe 'Romani' is the primary category for demarcating and racialising urban space (Kilibarda 2011). While their skin colour exposes them to racist profiling and microaggressions, they are not so readily racialised as Roma in the US, and therefore have more passing strategies (like describing themselves as Turkish) - and sometimes contrast Americans' 'ignorance' about Roma with 'blatant discrimination back home' when explaining why they left (Silverman 2012: 67, 69). The antiziganism of western and eastern Europe still confronts south-east European Roma living in France or Britain but is less tangible in the USA.

Studies of South Slav diasporas - which consist of several waves, formed for different prevailing reasons during economic depressions, regime changes and war (Pryke 2003; Cederberg 2005; Colic-Peisker 2008) - have also started asking how migrants interpret their new countries' configurations of race. Hariz Halilovich's translocal ethnography of Bosniak refugees from Prijedor and Srebrenica, for instance, suggested Bosnians in St Louis and Melbourne understood their own racialised position differently because of different US and Australian discourses of race. Bosnians in St Louis had internalised 'race ... as the source of their 
newly discovered white identity' (perceptible when they discussed the segregation of 'white' and 'African-American' neighbourhoods) more than Bosnians in Melbourne, who seemed 'much less attached to the colour of their skin and ... more ready to engage critically in deconstructing racial identities and prejudices against which they have not been completely immune' (Halilovich 2013: 228-9). These are translocal even more than transnational translations of race, with cities' immediate racial politics forming the everyday knowledge through which new Bosnian immigrants learned to racially position themselves - as events in Missouri after police killed Mike Brown would show (Croegaert 2015).

The Kosovo War, meanwhile, created new Albanian diasporas in countries like Britain, and enlarged existing ones (e.g. in Germany, the Netherlands, Sweden, the USA), just as migration studies was consolidating as a discipline, inspiring many studies of identities among their adolescent second and '1.5' generations (e.g. King and Mai 2008; Vathi 2015). These young people's everyday experiences were shaped by accommodating to the racial politics of multicultural London, Florence or Gothenburg (Vathi 2015: 105-8). Young Albanians in Britain, for instance, encountered the first wave of racialisation of 'east European' migrants which after 2004 would extend to Poles and other workers from new EU member states (see Fox, Moroşanu and Szilassy 2012). Albanians' location within racial formations in Italy illustrates Anthias and Yuval-Davis's argument (1993) that racism can take any 'biological, cultural, linguistic or religious' signifier as a boundary-marking symbol of difference, not just skin colour (King and Mai 2008: 4). While these diasporas do not contain people who any official Yugoslav ideology regarded as Yugoslavs, they overlap with the notion of 'diasporas from the Yugoslav region' in containing migrants from Yugoslavia's southern republics and their descendants, therefore should not be invisible in an argument about that notion. Moreover, the Kosovo War's sudden effect on how Kosovars and other Albanians in Europe were racialised also demonstrates how contingently people from the Yugoslav region fit into formations of 'race' elsewhere - an even more pressing question for Bosniaks and other Muslims after 9/11. 
Bosniak ethnicity, after $9 / 11$, stood at a specific intersection of identity and marginalisation. While Bosniaks' skin colour would racialise them as white-but-'ethnic' in the US, and white-but-linguistically-visible-aseastern-European in Europe, their religious heritage positioned them in the racialised, stigmatised and securitised category of 'Muslim. One outcome of this intersection, outside and inside Bosnia-Herzegovina, was presentation of Bosniak religious identity as a European Islam, a 'positive cultural exception' to other, non-tolerant and non-European Islams ascribed both to Islamic societies outside Europe and even to brown and black Muslim immigrants inside it (Bougarel 2007: 97). Another became identification with a transnational Muslim ummah. The Bosnian conflict itself popularised this idea among some Western Muslims, and as the War on Terror, state surveillance of Muslims and the distributed organisation of Islamist political violence intensified in the twenty-first century it would inspire small numbers of Bosniak and Kosovar youth (from the region and the diaspora) to 'make hijra' and join armed jihadist groups including ISIS (Chapter 4). A further intersection of religion, race and ethnicity with class - that many more rural Bosniaks practised religious tradition, while many urban Bosniaks' grand narratives of state socialism, modernity and the urban/rural divide associated religious practice with unmodernity - was common sense in south-east European identity discourses but little known outside diasporas in the countries where refugees moved (Al-Ali 2002).

Post-9/11 politics, Halilovich suggests, compelled Bosniaks in St Louis to identify with whiteness, anti-blackness and US performative patriotism (displaying flags outside houses) in order not 'to stand out as a minority' (Halilovich 2013: 218) - a decade after being persecuted in their home country for their ethnicity and religion - and to distance themselves from the threatening, racialised Muslim Other being 'cast out' (Razack 2008) from political communities across the West. Halilovich's book appeared a year before St Louis became a focus of African-American struggle - the site of Black Lives Matter's first street protest - in August 2014 when police in nearby Ferguson shot dead the black teenager Mike Brown. Racialised violence in St Louis affected Bosnians directly that November, 
when four African-American and Latino teenagers killed a Bosniak, Zemir Begić. Bosniaks' reaction, however, was more complex than a blanket identification with whiteness to explain the attack: while that did occur, young Bosniak women in particular viewed African-American experiences 'in relation to their own experiences with state violence, and lack of postwar justice, in Bosnia and through online activism articulated intersectional solidarities with African-Americans and Black Lives Matter (Croegaert 2015: 75). Young women's activism in this ' 1.5 generation' suggested Bosniaks' identification with whiteness was not predetermined; instead, Ana Croegaert (2015: 64) wrote, it showed how Bosnians could 'reject "whiteness" in favor of interracial solidarity informed by shared experiences with injustice, viewed through the lens of imperialism and empire' - another anti-imperialist identification grounded in the region's global history.

Bosniaks' racialisation, and other south-east European immigrants, since the 1990s has thus been a contingent process, not predetermined by their ethnicity and nationality. Indeed, this is no post-9/11 phenomenon, but has long been the case in settler colonial societies' migration history and labour history. A whole literature now asks how immigrants from Europe were racialised on arrival, how ascriptions of their racialised identity changed, and when and how they themselves understood their new countries' racial formations and their place(s) within them, with David Roediger (2005) influentially suggesting eastern Europeans did not know whiteness as a dimension of identity before needing to assimilate into it in the USA. Another well-known title, Noel Ignatiev's How the Irish Became White (Ignatiev 1995), encapsulates the idea that immigrants arriving from European peripheries (the Mediterranean, Ireland and central Europe as well as the Balkans), against nativist opposition, only gained gradual access to whiteness in the early twentieth century, and gained it by participating in structures of racialised oppression. This paradigm, of south and east Europeans arriving without consciousness of 'race' and acquiring whiteness by rejecting some solidarities and pursuing others, is migration history's prevailing mode of connecting eastern European identities and race under settler colonialism. 
White Anglophones at the 'centre' of their nations in Australia and New Zealand also equated whiteness with potential to assimilate. In the 1990s, Australian authorities attributed Bosnian refugees, including Muslims (who unlike Croats and Serbs were not joining an established diaspora), higher 'settlement potential' than non-white refugees, whom they perceived as 'culturally distant' - hence Val Colic-Peisker's telling quote, 'At least you're the right colour' (Colic-Peisker 2005: 618-19). Colic-Peisker (2005: 622) suggests identification with Europeanness as well as whiteness offered Bosnians 'emotional compensation for the loss of status' they experienced as refugees, restricted by linguistic and educational barriers from accessing skilled employment and fulfilling the 'settlement potential' that Australian racialised hierarchies of refugee resettlement had ascribed them.

In New Zealand, a century before, Dalmatian Croat labourers working on gumfields in the 1860s-1920s encountered a British imperial equivalent of the Ignatiev-Roediger pattern: core whiteness was Britishness, further whiteness was ascribed to ethnic groups in proportion to perceived assimilability, and the Croats themselves were racialised as socially and sexually disruptive to white morality, liable to be described as invasive 'locusts' just like Māori (Bozic-Vrbancic 2006: 186-7). By the mid-twentieth century, Croats' economic success in winemaking had opened whiteness up to them, while Māoris were campaigning to reconfigure national identity around Pākehā-Māori biculturalism. Biracial Māori-Croat children in the gumfields - possibly even the majority of children subjected to Native Schools' 'civilizing' mission (Timutimu, Simon and Matthews 1998: 111) there - experienced conditional identifications with both Māori and Pākehā culture and with a Dalmatia to which they often retained ties, while the advent of state socialism in Yugoslavia further complicated how they perceived the closeness or foreignness of this joint homeland (Bozic-Vrbancic 2005). Latenineteenth-century South Africa, meanwhile, probably (the census recorded migrants by origin country, not ethnicity) had some 2,000-2,500 Croats, including 400-500 miners at Kimberley. More than 400 Croats identifying themselves as 'traders, miners and all kinds of artisan' 
petitioned Vienna in 1899 to open a Pretoria consulate (Laušić 2003: 241-2). A comparative history of class, ethnicity and race is necessary to link these petitioners in South Africa, the gumfield labourers in New Zealand and the miners of the Mesabi Range in Minnesota - all present in the historical record (Laušić 2003; Bozic-Vrbancic 2005; Lubotina 2015) - plus others from the Yugoslav region into the global history of empire and labour.

Studies of other destinations also show how South Slav migrants, stratified by both ethnicity and class, have been accommodated within and altered those countries' formations of race. They did so as refugees in Nordic countries negotiating boundaries of whiteness, autochthony and immigration status (Cederberg 2005; Grünenberg 2005; Huttunen 2009; Valenta and Strabac 2011); as guest-workers in 1960s-70s West Germany, socio-economically similar to Turks and Kurds but racialised by white Germans somewhat differently (Molnar 2014); ${ }^{16}$ as migrants negotiating bourgeois belonging, whiteness, blackness and creoleness in turn-of-the-century Argentina; ${ }^{17}$ or as Zionists or Muslims migrating from south-east Europe to Palestine, movements through which both Dušan Bjelić (2017) and Darryl Li (2015b) revisit the history of 'Balkan postcoloniality'.

Li and Bjelić both produce 'connected histories' of two regions usually treated as separate by illustrating wider historical contexts through migration. Bjelić reads the 48,000 Bulgarian Jews who moved to Palestine in 1944-8 as 'agents of a double colonization', 'subjects of internal colonization' in Bulgaria who then came as 'colonizers' to Palestine; the implication is that 'the continuity of a single history over two geographies' is more accurate than Maria Todorova's separation of balkanism from orientalism (Bjelić 2017: 1-2). Li, meanwhile, translates and introduces a 1981 article by the anthropologist Nina Seferović about a hundred Muslim mujahir families who emigrated from Herzegovina to Caesarea after Bosnia-Herzegovina became an Austro-Hungarian protectorate in 1878. Their descendants, known as the Bushnaqs (from 'bošnjak' or 'Bosniak'), were displaced from Caesarea during the Nakba in February 1948, when 'their village ceased to exist' (Seferović 2015 [1981]: 77); 
the site became 'an affluent suburb' of Haifa, 'hosting Israel's only full-size golf course' (Li 2015b: 69). The (relatively light-skinned) Bushnaqs' migration history, reconstructed by Seferović, not only spotlights intraPalestinian dynamics of race and ethnicity but also, Li (2015b: 71) argues, illustrates an interpretive lens that faded after the break-up of Yugoslavia: while since the 1990s Bosnia and Palestine have usually been treated as separate but comparable, Seferović views them and Li revisits them as part of a single history with ties lasting across time.

The most sustained treatment of global raciality and migration from south-east Europe is, however, Miglena Todorova's study of the twentiethcentury circulation of people, media and racial formations between Bulgaria, the USA and the USSR. Todorova challenges the assumption that Bulgarian immigrants only learned identification with whiteness through living in the USA; instead, active translations of US biological and cultural racial thinking were already forming interpretive frames in Bulgaria for white Bulgarians' perceptions of Roma (Todorova 2006: 6-7). Bulgarian Communists also worked Stalinist notions of racialised differentials in modernity, then Cold War state socialist views of race, culture and development, into their racial formations. These translations of racialisation and whiteness thus did not only reach Bulgarians on migrating to the USA, as mainstream US labour/migration histories would suggest, nor did they travel solely around Atlantic coasts, as studies of race in translation (Goldberg 2009; Stam and Shohat 2012) usually emphasise; as asymmetric and contingent as they were, they certainly flowed in more than one direction. So too for the Yugoslav region.

\section{Conclusion}

Ethnicity and migration, two central topics for studies of the Yugoslav region, have been and are intimately linked to race: in the incorporation of racial theory into ethnonationalism, the hierarchies of belonging still present in cosmopolitanism or the adjustments that migrants from the region make to different racial politics abroad. All, moreover, exist 
within global, transnational and translocal frameworks shaped by European colonial domination. The lands of the Yugoslav region were not an imperial metropole, indeed were ruled for centuries by multiple imperial powers without extensive transoceanic colonies, and one such power - the Ottoman Empire - was itself 'non-European' in spatialised hierarchies of Europeanness, modernity and Christendom. Yet, even though the region's nations as political formations were not protagonists of colonial expansion, its people, businesses and capital from the region were still implicated, asymmetrically, in these structures, and as Tanja Petrović (2009: 55) observes: even 'representatives of states with no colonial legacy can also shape colonialist discourses. The Yugoslav region, and south-east Europe as a whole, is not beyond the remit of translocal imperial and colonial history, nor outside the global history of race.

Nevertheless, race as distinct from ethnicity has rarely, in south-east European studies, provided the kind of lens that might lead to longuedurée histories like Peter Fryer's Staying Power, on black people in Britain (Fryer 1984), or, for a spatially closer comparison, Allison Blakely's Russia and the Negro (Blakely 1986), published at a similar time and also intervening in public narratives about race, history and nation. Such histories are overdue. And yet Kesha Fikes and Alaina Lemon's important interpretive questions about identifying, determining and naming 'African presence' in the USSR would also apply here. By noticing the Soviet system had not offered territorialised identities to formerly enslaved Africans in the Caucasus but did recognise 'other formerly enslaved, likewise mobile - but "non-African" populations' as ethnonational groups with theoretical rights over territory, Fikes and Lemon identified an immediate racialised differential in Soviet nationalities policy, specific to Soviet and Transcaucasian history, that would refute claims that race was simply irrelevant for understanding Soviet Communism (Fikes and Lemon 2002: 500) - yet faced the problem of how to research race without further essentialising its boundaries.

Their solution, though written for the USSR, also helps integrate race into anti-essentialist studies of ethnicity in other regions. First, they reject the 'conceptual distancing' and exoticism of stating as an 
initial premise that Russia and Africa were 'hardly ... farther apart', and prefer to integrate these histories into the region's historical mainstream, altering how its centre is conceived in the process. Secondly, drawing on Gilroy (2000), Jacqueline Nassy Brown (the geographer of 'black Liverpool' (Brown 2009)) and Pratt, they argue the search for histories of black presence should begin, not with biologically predetermined concepts of blackness, but 'the social productions that make race recognizable'; diasporas, in turn, become 'meaningful "contact sites" that constitute power, place, and difference' rather than pre-set groups (Fikes and Lemon 2002: 498, 502). This resonates with a similar turn in the history and anthropology of south-east/central Europe towards studying the social production of ethnicity and nationhood. Moreover, it returns to the 'contact zones' with which this chapter began. The Yugoslav region, as glimpses of its 'cultural archive' show, has been such a zone for different nations, imperial projects and world-historical processes, the preconditions for its shifting identifications towards race. Indeed, we shall now see, the very range of racial formations that have circulated through it - from Venetian to German, from Soviet to NonAligned - are all ingredients for how those identifications are made.

\section{Notes}

1 On the Cold War politics of the US Civil Rights Commission naming past and present racialised violence against African-Americans as 'genocide' in petitioning the UN in 1951, see Martin (1997).

2 The term 'Četniks' for Serb paramilitaries derives from these 'čete' (bands), and was revived by Draža Mihailović's Serbian/Yugoslav royalist army in 1941-5, then during the Yugoslav Wars by paramilitaries who accompanied the Yugoslav People's Army, Army of the Bosnian Serb Republic (VRS) and Army of Yugoslavia (VJ) to attack non-Serb communities in Croatia, BosniaHerzegovina and Kosovo.

3 Serbian newspapers had already compared Serbia to Piedmont in 1861; the newspaper of the 'Ujedinjenje ili smrt' ('Unification or Death') society, founded in 1911, made 'Piedmont' an even bigger trope in narrating Serbia's geopolitical position and destiny (Mackenzie 1984: 174-5).

4 Habsburg visions included anational imperial identity (the Emperor); enforcing Magyar assimilationist policies on Croats and Serbs (Hungarian nationalists); 
and, shortly before 1914, constitutional reform involving a third, South Slav national unit (some South Slavs, plus Archduke Franz Ferdinand).

5 For a similar Bulgarian example, see Todorova (2006: 96-7).

6 A Jasenovac Memorial Centre list of 72,193 named victims identified 40,251 as Serbs (Kolstø 2011: 225). The 85,000-100,000 figure triangulates earlier demographic studies including unnamed victims (Dulić 2006: 271-3).

7 Bartulin's chief Croatian critic argues that the Ustaša blood descent principles expressed nationalism and showed no 'indication of racialist teaching or racism' (Jonjić 2012: 241).

8 Contemporaneous US racialisations of ethnicity meanwhile separated the 'Slavic' race, including Serbs and Croats, from the 'Mediterranean', including Greeks, Italians and Sicilians.

9 Forthcoming research by Sunnie Rucker-Chang on 'blackness' in Yugoslavia will cover the histories of black people in Ulcinj, African students in Yugoslavia (Chapter 3) and post-Yugoslav Roma.

10 With thanks to Florian Bieber.

11 Soviet media reported similarly on once-enslaved Africans in the Caucasus (Fikes and Lemon 2002: 513-15).

12 On the Seljans, see also Molvaer (2011) (the author is a retired Norwegian aid-worker). The Karlovac group were connected to Rijeka through descendants of Laval Nugent von Westmeath, an Irish-born Habsburg general awarded a castle there in 1826 whose ancestors had fled Ireland after the 1690 Battle of the Boyne; Laval's adoptive cousin branched the family out into Antigua.

13 For example, most operators of 'Chinese shops' come from two parts of Zheijang province (Qingtian County and Wenzhou); few Zheijangese work in other sectors; and most individuals stay only a few years, though a community persisting over time.

14 Bosnia-Herzegovina's Chinese population is approximately $10,000-12,000$, according to a study of migrant communities' visibility in urban space that connects a Bosnian market in St Louis, a Chinese market in Rajlovac (a periphery of Sarajevo) and a street of ex-Yugoslav cafes in Vienna (Sirbegović 2011).

15 The Dayton system, with ethnic quotas for major political posts, thus excluded both groups (Jews and Roma), newer migrants like the Chinese and older migrant minorities from full political participation. Benjamin Markin, a Ghanaian-Bosnian surgeon who came to Yugoslavia as a student, called himself 'the first "Sejdić-Finci" in $\mathrm{BiH}$ [Bosnia-Herzegovina]' - referring to a case two Bosnian Jewish and Romani activists had brought at the European Court of Human Rights - when interviewed as Bosnia-Herzegovina's new ambassador to Japan: 'Dr. Markin: ja sam prvi “Sejdić-Finci” u BiH', 24sata. info, 16 October 2013 (http://24sata.info/vijesti/bosna-i-hercegovina/166650-d r-markin-ja-sam-prvi-sejdic-finci-u-bih.html; accessed 11 September 2017).

16 Molnar argues that race did not determine Yugoslav guest-workers' experiences (because they were white, and perceptions of their difference from Germans were more linked to Cold War politics); yet that ascription of whiteness was still part of West German formations of race. 
17 Migration from the region to Argentina, like South Africa, is under-researched compared with migration to North America or even Australasia - yet entailed no less complex and no less unique translations of race. See, for instance, the surprising appearance of Korčula's Moreška dance (see Chapter 3) in the Argentinian newspaper La Prensa's carnival reviews: in the 1901 Buenos Aires carnival, a troupe called Perla del Plata from the immigrant district of La Boca 'dressed as montenegrinos (people from Montenegro) and danced with "great precision and elegance" a "moorish dance," which La Prensa understood to be "from the epoch in which the Republic of Genova, owner (sic) of a great portion of Greece and the coasts of Africa, held this dance in high regard"' (Siegel 2000: 70). Many such performances involved blackface (Siegel 2000: 69). Here is not only a(nother) conflation of Africanity and Montenegrin identity through 'black'-ness, but elisions of Genoa/Venice and the northern/southern Mediterranean - at least as reported to these readers in Buenos Aires. 